192 Archives of Disease in Childhood, 1986, 61

Table Diagnoses and results of the radionuclide tests in the 50 infants

\begin{tabular}{|c|c|c|c|c|c|c|c|c|}
\hline \multirow[t]{2}{*}{ Diagnosis } & \multirow[t]{2}{*}{ No } & \multicolumn{4}{|l|}{$D I S I D A$} & \multicolumn{3}{|c|}{ Rose-Bengal } \\
\hline & & $\begin{array}{l}\text { No } \\
\text { excretion }\end{array}$ & $\begin{array}{l}\text { Rapid } \\
\text { excretion }\end{array}$ & $\begin{array}{l}\text { Delayed } \\
\text { excretion }\end{array}$ & Not done & $<10 \%$ & $>10 \%$ & Not done \\
\hline Biliary atresia & 21 & 20 & 0 & 0 & 1 & 14 & 0 & 7 \\
\hline Bile duct plug & 1 & 0 & 0 & 1 & 0 & 0 & 0 & 1 \\
\hline$\alpha_{1}$ Antitrypsin deficiency & 6 & 0 & 1 & 1 & 4 & 1 & 0 & 5 \\
\hline Hepatic disease & 22 & 3 & 5 & 1 & 13 & 3 & 3 & 16 \\
\hline Total & 50 & 23 & 6 & 3 & 18 & 18 & 3 & 29 \\
\hline
\end{tabular}

\section{Discussion}

A skilfully interpreted percutaneous liver biopsy specimen and ${ }^{131}$ I Rose-Bengal faecal excretion test have been shown to discriminate between biliary atresia and hepatic disease once genetic disorders have been excluded. ${ }^{3}$ Neither test alone is reliable. The use of ${ }^{131} \mathrm{I}$ as a tracer in infancy is not ideal as it is a beta emitter with a long half life, although the dose is very small. The test also involves collection of stools for three days, carefully avoiding urinary contamination that may invalidate the result. This study suggests that DISIDA scintigraphy after treatment with phenobarbitone is as accurate as the Rose-Bengal test. Whether it is necessary to use phenobarbitone is uncertain. ${ }^{4}$ It was used in this study because five of seven infants with hepatic disease had no excretion of paraisopropyl IDA when tested without phenobarbitone but did excrete after treatment with phenobarbitone. ${ }^{6}$

DISIDA scintigraphy has the drawback that it is subjective, allowance having to be made for isotope in the kidneys and bladder, and time consuming. Assessment of hepatic uptake of DISIDA may increase diagnostic accuracy. ${ }^{45}$ Nevertheless, when used in conjunction with ultrasonography, tests for infective and genetic causes of liver damage, and percutaneous liver biopsy DISIDA scintigraphy represents a considerable advance in distinguishing $\vec{\sim}$ complete from partial cholestasis in early infancy.

We thank Pamela Golding for typing the manuscript and Dr $J$ Barrett, Nuclear Medicine Department, for his help.

\section{References}

1 Kasai M. Advances and treatment of biliary atresia. Jpn J Surg 1983;13:265-72.

${ }^{2}$ Markowitz J, Daum F, Kahn EI, et al. Arteriohepatic dysplasia. 1. Pitfalls in diagnosis and management. Hepatology 1983;3: 74-6.

${ }^{3}$ Manolaki AG, Larcher VF, Mowat AP, Barrett JJ, Portmann B, Howard ER. The prelaparotomy diagnosis of extrahepatic biliary atresia. Arch Dis Child 1983;58:591-4.

4 Gerhold JP, Klingensmith WC, Kuni CC, et al. Diagnosis of biliary atresia with radionuclide hepatobiliary imaging. Radiology 1983;146:499-504.

5 Leonard JC. Hitch DC, Manion CV. The use of diethyl-IDA $99^{\mathrm{m}}$ technetium clearance curves in the differentiation of biliary atresia from other forms of neonatal jaundice. Radiology 1982;142:773-6.

${ }^{6}$ Majd M, Reba RC. Altman R. Hepatobiliary scintigraphy with $99^{\mathrm{m}}$ TC PIPIDA in evaluation of neonatal jaundice. Pediatrics $1981: 67: 140-5$.

Correspondence to $\mathrm{Dr}$ A P Mowat, Consultant Paediatrician, Department of Child Health, King's College Hospital. Denmark Hill, London SE5 8RX.

Received 30 October 1985

\title{
Splenunculectomy in thrombocytopenic purpura
}

\section{M REID, P W G SAUNDERS, J D FENWICK, AND W WALKER}

Departments of Haematology, Royal Victoria Infirmary and Newcastle General Hospital, and Regional Medical Physics Department, Newcastle General Hospital, Newcastle upon Tyne

SUMMARY In six patients with thrombocytopenic purpura not cured by splenectomy platelets fell to $<150 \times 10^{9} / 1$ within six weeks of splenectomy. They 'failed to respond'. Two underwent splenuncu- lectomy without improvement. Splenunculectomy $\stackrel{\odot}{\rightarrow}$ offered little chance of improvement to published 7 cases who failed to respond but may well be helpful after true relapse. 
A small proportion of children with persisting idiopathic thrombocytopenic purpura are not cured by splenectomy. ${ }^{1}$ It has long been postulated that enlarged accessory spleens may be responsible for recurrent thrombocytopenia in some splenectomised patients, and splenunculectomy has cured or improved several such patients. ${ }^{2-5}$

With this aim we reinvestigated seven patients who were not cured by splenectomy and offered splenunculectomy to those with persistent bruising in whom an accessory spleen was shown.

\section{Methods}

Platelets were labelled with ${ }^{111}$ In-oxine under aseptic conditions. Eight $\mathrm{MB}_{\mathrm{q}}$ of labelled platelets were injected intravenously and anterior and posterior abdominal scintigraphs obtained at one hour and one, two, and three days with a gammacamera.

\section{Patients}

The seven patients were aged between 4 and 12 years (mean 8 years) at the onset of the purpura. Splenectomy was performed between one and four years (mean two years) after diagnosis. The response to splenectomy in the seven patients is shown in the Figure. Case 7 became thrombocytopenic and started bruising again at one year after splenectomy. Indium scans were obtained between two and
19 years (mean 10 years) after splenectomy. Enlarged accessory spleens were found in cases 1 to 4 . Cases 3 and 4 underwent splenunculectomy. Neither was improved.

\section{Discussion}

The response to splenunculectomy in cases 3 and 4 was disappointing and caused us to review more critically the published reports. The role of splenunculectomy in patients with idiopathic thrombocytopenic purpura who have not been cured by splenectomy has been obscured by loose use of the term 'recurrent' and by widely differing interpretations of what constitutes a remission. For example, Wallace et al required a platelet count $>150 \times 10^{9} / 1$ at an unspecified time after splenectomy, ${ }^{3}$ and Verheyden et al, in their survey of cases in the English reports, included two whose post splenectomy 'remissions' lasted only 12 and 30 days. ${ }^{4}$

In our experience some rise in the platelet count occurs in almost all children with idiopathic thrombocytopenic purpura immediately after splenectomy, but it is unlikely to be sustained unless the count exceeds $300 \times 10^{9} / 1$ in the first week. ${ }^{1}$ It is also clear from the patients shown here that such a rise does not guarantee cure. We classified empirically those patients not cured by splenectomy whose counts fell below $150 \times 10^{9} / 1$ within six weeks, irrespective of their peak concentrations, as having




idiopathic thrombocytopenic purpura that 'failed to respond' to splenectomy. Only case 7 could be considered to have a true relapse of the purpura, and he did not have an enlarged accessory spleen.

Despite clinicians' enthusiasm for removing accessory spleens, this operation has produced a remission in less than a third of cases presenting up to $1981 .{ }^{34}$ Application of our criteria to these cases suggests that half of those with true relapses of idiopathic thrombocytopenic purpura responded while none who failed to respond to splenectomy did. To this latter group may now be added our own two patients. In 1981 Pawelski et al described 12 patients with apparently true relapses of the purpura after splenectomy, all of whom were cured by splenunculectomy. ${ }^{5}$

Purpura that fail to respond to splenectomy should be distinguished from true post splenectomy relapses. This has not been the case in the past. Although the number of children not cured by splenectomy in our centre is small, we believe that criteria such as ours (platelets $<150 \times 10^{9} / 1$ within six weeks of splenectomy) may identify a group of patients very unlikely to respond to splenunculectomy. Patients who have had a true relapse of the purpura after apparently $\stackrel{\vec{S}}{\rightarrow}$ successful splenectomy in whom an enlarged acces- $\bar{T}$ sory spleen is shown may well benefit from its removal.

The authors thank Miss J Gibson for meticulous record keeping and for plotting the platelet counts.

References
1 Walker R, Walker W. Idiopathic thrombocytopenia, initial
illness and longtcrm follow up. Arch Dis Child 1984;59:316-22.
2 Hann IM, Wainscoat JB. Recurrent thrombocytopenic purpura
associated with accessory spleen. Arch Dis Child 1976;51:154-6.
3 Wallace D, Fromm D, Thomas D. Accessory splenectomy for
idiopathic thrombocytopenic purpura. Surgery 1982;91:134-6.
4 Verheyden CN, Beart RW, Clifton MD, Phyliky RL. Accessory
splencctomy in management of recurrent idiopathic thrombocy-
topenic purpura. Proceedings of the Mayo Clinic 1978;53:442-6.
5 Pawelski S, Konopka L, Zdziechowska H. Recurrence of
thrombocytopenia in patients splenectomized for idiopathic
thrombocytopenic purpura. Blut 1981;43:355-60.

Correspondence to Dr M M Reid, Department of Hacmatology, Royal Victoria Infirmary, Newcastle upon Tyne NE1 4LP.

Received 21 October 1985

\title{
Pancytopenia caused by iron-dextran
}

\author{
H HURVITZ, E KEREM, E GROSS-KIESELSTEIN, A BRAND, AND D BRANSKI \\ Department of Pediatrics, Bikur Cholim General Hospital, Jerusalem, Israel
}

SUMMARY Pancytopenia after intramuscular irondextran treatment occurred in an infant with Down's syndrome. Haematological abnormalities recurred on subsequent challenge. Positive migration inhibiting factor and mast cell degranulation tests support an allergic pathogenesis for the pancytopenia. These side effects have not been reported previously.

Severe, even fatal, allergic reactions are known to occur after parenteral administration of irondextran (Imferon). We describe a patient who developed thrombocytopenia, leucopenia, and haemolytic anaemia after intramuscular injection of iron-dextran. These haematological abnormalities recurred on subsequent challenge.

\section{Case report}

A 1 year old girl with Down's syndrome was admitted to our department. Blood count showed an iron deficiency anaemia with haemoglobin concentration $83 \mathrm{~g} / \mathrm{l}$, packed cell volume $0 \cdot 28$, mean corpuscular volume $71 \mathrm{fl}$, leucocytes $8 \times 10^{9} / 1(70 \%$ neutrophils, $12 \%$ band forms, $16 \%$ lymphocytes, $2 \%$ monocytes), and platelets $165 \times 10^{y} / 1$. Serum iron concentration was $2.3 \mathrm{mM} / 1(12.7 \mu \mathrm{g} \%)$. Iron binding capacity was $55 \mathrm{mM} / \mathrm{l}(307 \mu \mathrm{g} \%)$. Intramuscular iron-dextran $(30 \mathrm{mg} / \mathrm{kg})$ was given in three divided doses over six days because of feeding problems and poor compliance. Ten days later the haemoglobin concentration rose to $98 \mathrm{~g} / \mathrm{l}$, and the reticulocyte count was $4 \cdot 8 \%$. The leucocyte count was $9.7 \times 10^{9} / 1$ with normal differential count, and the platelet count was $180 \times 10^{9} / 1$. She was discharged home but was readmitted to hospital one month later. Her blood count showed pancytopenia with haemoglobin concentrations $74 \mathrm{~g} / 1$, packed cell volume 0.24 , mean corpuscular volume $85 \mathrm{fl}$, leucocytes $3.3 \times 10^{9} / 1$ (49\% neutrophils, $4 \%$ band forms, $43 \%$ lymphocytes, $2 \%$ monocytes, and $2 \%$ eosinophils), and platelets $\overline{50} \times 10^{9} / 1$ (Figure). Direct and indirect Coombs' tests were negative, her glucose-6-phosphate concentration was normal, and 